\title{
Article \\ Understanding the Cognitive Components of Coastal Risk Assessment
}

\author{
Maria Francesca Bruno *(D), Giulia Motta Zanin (D), Angela Barbanente (D) and Leonardo Damiani (iD) \\ Department of Civil, Environmental, Building Engineering and Chemistry, Polytechnic University of Bari, \\ Via Orabona 4, 70125 Bari, Italy; giulia.mottazanin@poliba.it (G.M.Z.); angela.barbanente@poliba.it (A.B.); \\ leonardo.damiani@poliba.it (L.D.) \\ * Correspondence: mariafrancesca.bruno@poliba.it
}

check for updates

Citation: Bruno, M.F.; Motta Zanin,

G.; Barbanente, A.; Damiani, L.

Understanding the Cognitive Components of Coastal Risk

Assessment. J. Mar. Sci. Eng. 2021, 9,

780. https://doi.org/10.3390/

jmse 9070780

Academic Editor: Tom Spencer

Received: 25 June 2021

Accepted: 17 July 2021

Published: 18 July 2021

Publisher's Note: MDPI stays neutral with regard to jurisdictional claims in published maps and institutional affiliations.

Copyright: (c) 2021 by the authors. Licensee MDPI, Basel, Switzerland. This article is an open access article distributed under the terms and conditions of the Creative Commons Attribution (CC BY) license (https:/ / creativecommons.org/licenses/by/ $4.0 /)$.

\begin{abstract}
Nowadays, erosion and flooding risks represent a serious threat to coastal areas and this trend will be worsened due to climate change. The increasing concentration of population in coastal areas has a negative impact on the coastal ecosystem due to change in land use and the exploitation of natural resources, which has also increased exposure to coastal hazards. Risk assessment is hence a primary topic in coastal areas and are often affected by mismanagement and competition of interest between stakeholders. This paper presents an integrated model for coastal risk assessment as well as its application on a test site in the Puglia Region (Southern Italy). An innovative approach has been developed combining a traditional index-based model, exploiting a Drivers-Pressures-StateImpact-Response framework (DPSIR), with stakeholder's and policy makers' engagement by using the Future Workshop method and complementary individual working sessions structured through the use of Fuzzy-Cognitive Maps. The study shows that stakeholders' and policy makers' risk perception play a key role in coastal risk management and that the integration of physical risk with social perception is relevant to develop more effective management following the basics of Integrated Coastal Zone Management.
\end{abstract}

Keywords: coastal risk assessment; DPSIR; risk perception; fuzzy cognitive maps; climate change

\section{Introduction}

Nowadays erosion and flooding risks represent a serious threat to coastal areas and this trend will get worse in the future due to climate change and growing urbanization processes [1-3]. According to the framework of Crichton's Risk Triangle [4], risk depends on the combination of hazard, exposure, and vulnerability where a hazard is the source of potential damage, exposure represents the elements affected by a hazard, and vulnerability describes the propensity of exposed elements to be damaged by a hazard event [5]. The natural environment and sustainability of coastal areas are becoming increasingly degraded by erosion and flooding hazards that are boosted by climate change [6,7]. Sandy beach evolution has been projected under different scenarios and an overall erosive trend of sandy beaches that increases in time and with the intensity of Representative Concentration Pathways scenarios (RCP 4.5 and 8.5) has been predicted [6]. By the end of the century, under RCP 8.5, about $63 \%$ of the world's sandy beaches in low-elevation coastal zones with high population density could be affected by erosion. Moreover, a tremendous increase in coastal areas exposed to episodic coastal flooding ( $+48 \%$ compared to the present day), consequently impacting more people $(+52 \%)$ has been reported when considering the worst scenario (RCP 8.5) [7].

The increasing concentration of population in the coastal areas has a negative impact on the coastal ecosystem due to the land use change and overexploitation of natural resources [3,8,9], also increasing exposure to coastal hazards. Accordingly, the ability to adapt and overcome a hazardous event, termed coastal resilience, is reducing such exploitation and allowing coastal systems the long recovery times that they require $[10,11]$. 
Risk assessment is hence a primary topic in coastal areas and several conceptual frameworks, methods, and GIS-based tools [12-15] have been developed in the last decades, including also climate change projections [16]. A useful toolkit has been also developed by Van Dongeren et al. [15] to reduce risk and increase the coastal resilience by adopting a two-step assessment procedure: After the identification of coastal hot spots at a regional scale, a high resolution HotSpot tool helps in evaluating Disaster Risk Reduction measures. The index-based approach is the most common methodology [17] and numerous indices have been proposed starting from the Coastal Vulnerability Index (CVI) [18]. In addition, coastal systems are often affected by mismanagement and conflicts due to different actor's interests $[19,20]$. In the modern age, defense structures against sea and weather events have been built, producing a stiffening of coastal systems. This "hard approach" to coastal management has led to settlements that are more protected but less able to adapt to subsequent changes in an environmental context [21]. Despite the development of construction techniques and hydraulic sciences, coastal protection structures could have the opposite effect to expectations. As a matter of fact, these hard approaches used for many decades as the only way to manage coastal risks, have often proved unsuccessful and inefficacious [21,22].

Thus, coastal area management is a very complex topic since it requires the integration of regulatory, technical, economic, cultural, and social aspects [23,24]. These aspects have all been covered by the Integrated Coastal Zone Management (ICZM) [25], but this approach is far from being put into practice and therefore requires further study and experimentation [26]. Furthermore, a thorough knowledge of natural ecosystems and their interaction with human society can help in reducing coastal vulnerability reduction and enhancing resilience [3,27].

Hence, the assessment of the main physical drivers of erosion and flooding needs integration with the investigation of stakeholders' and local communities' perception, knowledge, and interactions with coastal environment [28-31]. The Sendai Framework for Disaster Risk Reduction 2015-2030 [32] also highlights the importance of sharing knowledge and pragmatic guidance in the development of local, national, regional, and global plans and strategies with stakeholders, including local government, the private sector, and others. In line with this, new management activities are required based on a reliable, understandable, and timely knowledge of processes affecting coastal hazards, getting decision makers, stakeholders, and local communities involved [33].

Risk perception is commonly evaluated via questionnaires and structured and semistructured interviews [28-31,34-36]. Stakeholders perception and awareness of coastal risk have been also investigated through discussion workshops aimed at developing future scenarios [37,38].

The perception elicited among different actors (e.g., decision-makers, coastal managers, and residents) often results in diverse levels of perceptions, in which residents usually perceive lower levels of risk instead of coastal managers [28]. Low awareness of erosion and beach management concepts is also generally found in beach users [34]. Thus, social risk perception is of fundamental importance in the adoption of management strategies and their approval, since a well-informed and prepared community recovers soon from short-term weather and climate-related events [39]. Consequently, long-term impacts on human health, natural environment, and economy can be significantly reduced by a higher level of resilience.

This paper presents an integrated model for coastal risk perception assessment as well as its application on a test site in Puglia Region (Southern Italy). An innovative approach combining a traditional index-based model proposed by [27] with stakeholders engagement has been developed by using the Future Workshop method [40] and complementary individual working sessions [23,41]. Thanks to the derived Fuzzy Cognitive Maps [42,43], the developed procedure has provided a wide framework of the stakeholders' perception and awareness of coastal processes and management. 
The paper is structured as follows: Section 2 provides details on the index-based approach and process to investigate policy makers' and stakeholders' risk perception; Section 3 illustrates the features of the study area; and in Section 4 the obtained results are presented. Section 5 contains the discussion on the proposed scheme and in Section 6, conclusions are provided.

\section{Method}

The integrated model for coastal risk assessment has been designed and structured in five steps as shown in Figure 1. Step 1 focuses on the evaluation of the physical coastal risk by using the Modified EUrosion Model; Step 2, 3, and 4 aim at understanding the level of coastal risk perception and awareness of stakeholders and policy makers; and Step 5 regards the evaluation of Coastal Vulnerability and Exposure indexes by local actors.

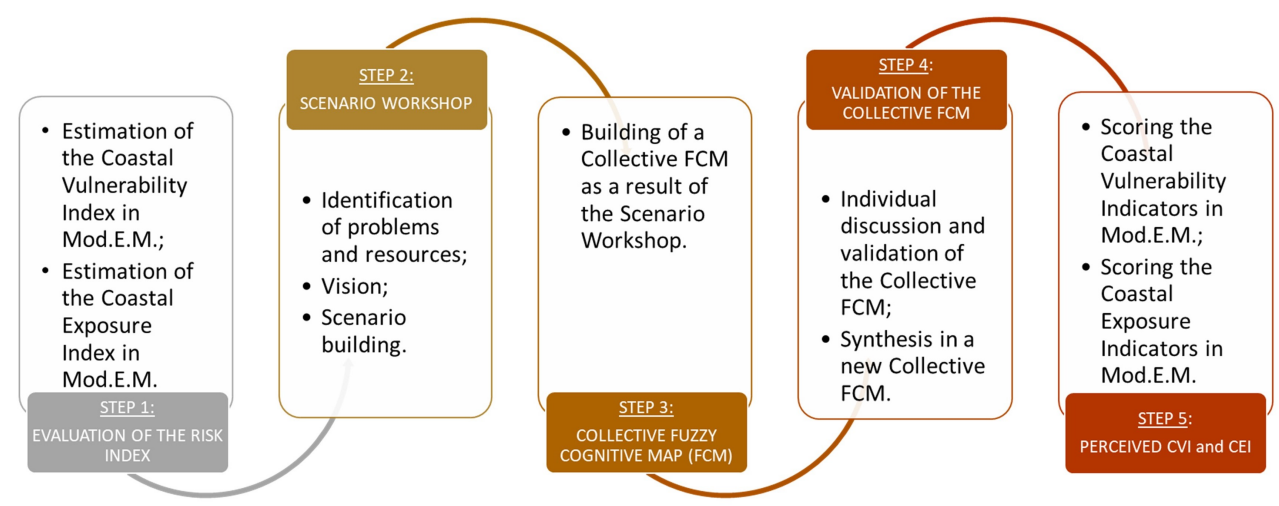

Figure 1. Integrated model for coastal risk assessment.

\subsection{Step 1: The Physical Coastal Risk}

The Drivers-Pressures-State-Impact-Response (DPSIR) conceptual framework is a popular approach to risk assessment [44], enabling a better understanding and a detailed description, using a multivariate analysis, of current or expected issues, and their potential evolution at different scales. Currently, the DPSIR approach is applied to investigate and outline the processes and the cause and effect relationships between Drivers and Pressures that alter the current State and then the Impacts on the environment, economy, and society [44]. The EUrosion project [45] applied the DPSIR framework to coastal erosion and flooding and defined a series of indicators able to describe the linkage between cause and effects. The Modified EUrosion Model (Mod.E.M.) was developed from the classic EUrosion approach [45] exploiting a detailed analysis of the Path of Effects (PoE) in the Puglia region (Figure 2), which helped select new indicators to be effectively used in coastal risk assessment [27].

Using this approach, the Coastal Risk Index (CRI) is calculated as a product of the Coastal Vulnerability Index (CVI) and the Coastal Exposure Index (CEI) which represents the tendency for erosion and/or flooding and the exposure of the natural and anthropic environment, respectively. 


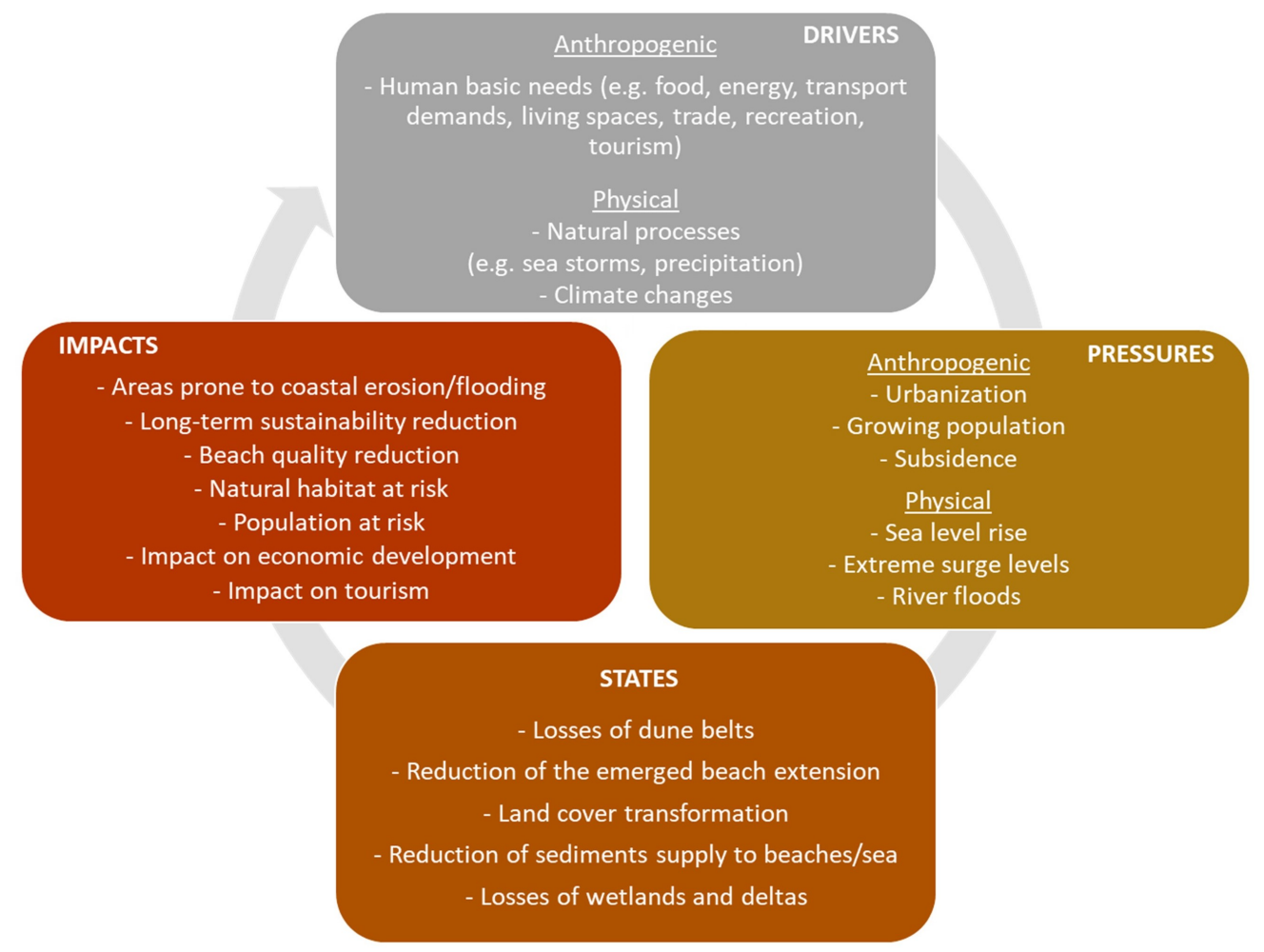

Figure 2. Risk profile-DPSIR Path of Effects (PoE).

The Vulnerability and Exposure indicators employed in the Mod.E.M. approach are outlined in Equations (1) and (2) and Table 1 reports the score ranges that can be assigned to the indicators. Elevation data, historical maps, censuses, flooding hazard maps, and land use maps contribute to the estimation of the indicators together with climate change projections. The indicators are estimated by reference to the RICE area that is defined as all areas that could be affected by erosion and flooding in the next 100 years, located within $500 \mathrm{~m}$ from the shoreline and that can be extended to low-lying areas (under $+5 \mathrm{~m}$ above sea level) [45]. Indicators are scored between 0 (lowest level) and 2 (highest level) according to Table 1. For a more detailed explanation of all indicators and datasets, readers can refer to Bruno et al. [27].

$$
\begin{gathered}
C V I=S L R+H W L+A_{R I C E}+G E C+E S R L+H H_{R I C E} . \\
C E I=U_{R I C E}+E_{R I C E}+U_{10 K m}+P_{\text {RICE }} .
\end{gathered}
$$

After a critical analysis of the risk profile in coastal risk assessment, the Mod.E.M. approach has been developed to cover elements not included in the original EUrosion model such as past erosive processes, river flood hazards, and seasonal population.

Hence, the new ESRL indicator takes into account the long-term shoreline evolution trend together with the most recent evolution, by considering the weighted sum of Recent Shoreline Erosion (RSE) assessed in the last 15 years (weight 0.7) and Past Shoreline Erosion (PSE) reported in the previous decades (weight 0.3).

Moreover, since high river discharges and severe storm surges can occur at the same time, the riverine inundation has also been included in the vulnerability by means of the new $H H_{\text {RICE }}$ indicator [46-48].

To also take into account the large number of visitors that reach the coastal area in the summer period, both seasonal population and residents are considered in the estimation of the $P_{\text {RICE }}$ indicator. 
Table 1. Ranking scores of CVI and CEI used in Mod.E.M. [27].

\begin{tabular}{|c|c|c|c|}
\hline \multirow{2}{*}{ Coastal Vulnerability Indicators } & \multicolumn{3}{|c|}{ Scores } \\
\hline & 0 & 1 & 2 \\
\hline SLR: Average speed of Sea Level Rise (mm/yr) & $<0$ & $0-4$ & $>4$ \\
\hline HWL: Highest water level (m) & $<1.5$ & $1.5-3$ & $>3$ \\
\hline PSE: Past shoreline erosion (\%) & $<20$ & $20-60$ & $>60$ \\
\hline RSE: Recent shoreline erosion (\%) & $<20$ & $20-60$ & $>60$ \\
\hline$H_{\text {RICE }}:$ Hydraulic hazard in RICE (\%) & $<10$ & $10-20$ & $>20$ \\
\hline GEC: Coastal Geology- Rocky shoreline (\%) & $>70$ & $40-70$ & $<40$ \\
\hline$A_{\text {RICE }}:$ Municipal area in RICE $(\%)$ & $<5$ & $5-10$ & $>10$ \\
\hline ESRL: Eroded shoreline & \multicolumn{3}{|c|}{0.7 RSE + 0.3 PSE } \\
\hline \multirow{2}{*}{ Coastal Exposure Indicators } & \multicolumn{3}{|c|}{ Scores } \\
\hline & 0 & 1 & 2 \\
\hline$U_{R I C E}:$ Urban and/or industrial area in RICE (\%) & $<10$ & $10-40$ & $>40$ \\
\hline$E_{\text {RICE }}$ : High ecological value areas in RICE (\%) & $<5$ & $5-30$ & $>30$ \\
\hline$P_{\text {RICE }}$ : Resident and seasonal population in RICE (1000 hab.) & $<5$ & $5-20$ & $>20$ \\
\hline$U_{10 \mathrm{~km}}:$ Increase in urban area in a $10-\mathrm{km}$ wide coastal area $(\%)$ & $<5$ & $5-10$ & $>10$ \\
\hline
\end{tabular}

\subsection{The Perceived Coastal Risk}

Risk perception was investigated to understand the level of awareness that policy makers and stakeholders have on coastal erosion processes and associated risks. The authors designed, organized, and guided the whole process. Firstly, a Scenario Workshop was designed and organized to allow to imagine future solutions to current problems by involving key representatives of the decision-making system and local society, in a process that starts from the definition of current problems, identifies possible solutions, and the ways to put them into action [49]. Secondly, to better understand the level of local actors' risk perception, a Collective-Fuzzy Cognitive Map (C-FCM) was graphically represented. Thirdly, the Collective FCM was submitted to each actor for validation and then synthesized in a new Collective-FCM. Finally, the Mod.E.M. method was presented to the actors and they were asked to score the Coastal Vulnerability Indicators (CVI) and Coastal Exposure Indicators (CEI) in order to allow a comparison between the perceived and physical coastal risk.

\subsubsection{Step 2: The Scenario Workshop}

Policy makers' and stakeholders' risk perception was investigated through the organization of a Scenario Workshop. As described by [23], it was based on the Future Workshop approach [40], which aims, through three main phases (critique, fantasy, and implementation) to change or transform the present systems' condition, stimulating participants' opinions on the potential solutions within the future scenarios by the year 2040 [50].

As shown in Figure 1, the Scenario Workshop started with the problems and resources identification, continued with the vision, and concluded with the building and implementation of the scenario [23].

Fifteen participants were identified, representing four categories of actors to allow the broadest representation of the interests: (i) Policy makers (regional, provincial, and local), (ii) technicians, (iii) representatives of a main local economic system, and (iv) local environmental associations.

\subsubsection{Step 3: The Collective-Fuzzy Cognitive Map}

To investigate the results of the Scenario Workshop, a Collective-Fuzzy Cognitive Map (C-FCM) was built using the Vensim software [41]. FCMs can effectively represent human knowledge and experience by introducing concepts to show the essential elements and cause and effect relationships between concepts to model the behavior of any system [51]. 
This method allows to graphically represent relations between variables previously described by people [42,52]. The software uses the fuzzy logic, "to incorporate vague and qualitative knowledge" [52]. FCMs are represented as oriented graphs with feedback, which consist of nodes (or concepts, Ci), being the variables, connected by weighted arcs (or connections, Wi) [41,52]. Furthermore, each node can be related to the other, positively or negatively.

\subsubsection{Step 4: The Validation of the Collective-Fuzzy Cognitive Map}

To discuss and validate the C-FCM as a result of the Scenario Workshop, individual online working sessions were organized. This step was supposed to be organized as a collective session. However, due to the COVID-19 pandemic, the only legal way to perform it was to redirect it in an online form. To allow a more effective result of this step, individual online meetings were organized with each of the four categories of actors previously involved in Step 2. During the online working sessions, each actor was asked to discuss, modify, and validate the C-FCM. The results of each individual session corresponded to an Individual-FCM (I-FCM). After all the sessions, a new C-FCM was built as a result of the I-FCMs, bringing out the major points of discussion, the parts that remained unchanged, and those that were added.

\subsubsection{Step 5: Evaluation of CVI and CEI Indices by Stakeholders and Policy Makers}

To allow comparison between the physical coastal risk calculated through the Mod.E.M. method and the perceived risk, at the end of the online working sessions carried out in Step 3, each actor was asked to give scores (from 0 to 2 ) to coastal vulnerability and exposure indicators of the Mod.E.M. method for the study area.

\section{The Study Area: Margherita Di Savoia (Puglia Region, Southern Italy)}

Puglia region is situated in south-eastern Italy and along its $975-\mathrm{km}$ coastline, several topographic, geological, and morphological features can be detected [27]. Coastal erosion and flooding severely affect the regional coastline with heavy economic impacts on traditional maritime activities, agriculture, and tourism [53-55]. The coastal town of Margherita di Savoia lies in the Adriatic Sea along the Gulf of Manfredonia (Figure 3) and it is famous for its 18-km coastline. It is a singular place because it is enclosed between the sea and the 4500 hectares of saltmarshes.

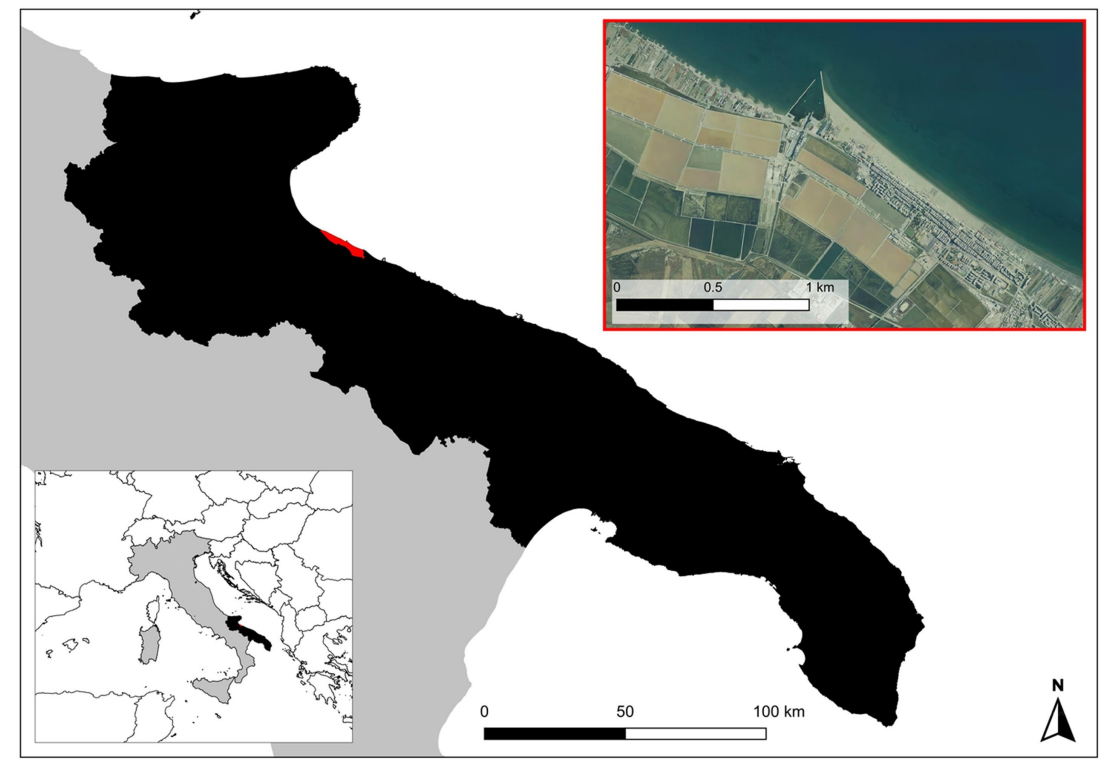

Figure 3. Framing the study area of Margherita di Savoia (Puglia Region, Southern Italy). 
The origin and development of this small town of almost 11,000 inhabitants is closely related to the saltworks and their use. The coastal landscape, once characterized by large swampy plains, has been profoundly transformed by the reclamation and cultivation of the Salso and Salpi Lakes, which started at the end of the 19th century and then were realized from the 1930s onwards by the Consorzio di Bonifica della Capitanata, whose waters have also been used to expand the saltworks [56]. During the last 70 years, this coastal area experienced an increase in urbanization and intensification of land use. Nowadays, the relationship between the inhabitants and sea-related economic activities is still strong. The coastal area of Margherita di Savoia is characterized by many different uses and activities such as beach tourism and related activities, harbor activities, residential use, agriculture, and saltworks. Besides being known as the town of saltworks, it is also known nationally and abroad as a place of origin of top quality agricultural products, grown on the sandy shores [56]. Moreover, the presence of protected natural areas, wide beaches, and thermal springs makes the area attractive for regional tourists and the population largely increases in the summer period. Indeed, in the year 2019, it registered almost 11,000 tourist arrivals [57].

The coastal area is a well-known hot spot for coastal erosion and flooding, due to the presence of long sandy coastlines and low inland heights [27]. These phenomena are strongly impacting economic activities and land use, threatening beach tourism and agriculture [58]. The area is mainly constituted by sandy foreshore, affected from a clear erosion process caused by both natural and anthropogenic causes. Following the sediment supply reduction from the Ofanto river caused by dams construction, up to $600 \mathrm{~m}$ of shoreline retreat occurred along the delta between 1960 and 2017 [27,59-61]. Moreover, in the same period, the riverine sediment loss together with the harbor breakwater construction has triggered severe shoreline erosion in the northern coastline. To contrast the coastal erosion along the coastline in the Gulf of Manfredonia, more than 400 groynes have been built that have only shifted the erosive process to the shoreline in the west without any improvement $[23,27]$. Nowadays the erosion is moving slightly from the Ofanto river mouth towards the north and even in the northernmost beaches protected by groynes, the shoreline has retreated. On the contrary, in the eastern part of the harbor, a wide beach formed after the harbor breakwater construction, resulting in intense beach tourism exploitation. The harbor entrance is also affected by significant sediment deposition and the need for maintenance dredging [62].

\section{Results}

\subsection{The Physical Coastal Risk in the Test Site}

The physical coastal risk is assessed using the Mod.E.M. method [27]. Figure 4 reports the eroded shoreline, flooding areas, and land use. The CVI and CEI indicators together with their scores in the range 0 (lowest) to 2 (highest) are also shown in Figure 4.

In the pilot area, a high value of CVI can be found. According to Vousdoukas et al. [63], Sea Level Rise (SLR) under RCP 2.6 and Highest Water Level (HWL) are expected to be $0.35 \mathrm{~m}$ and $0.90 \mathrm{~m}$, respectively, assigning a medium and low score. Considering the higher emissions scenarios, the SRL indicator reaches the highest score (SLR is expected to be $0.45 \mathrm{~m}$ under RCP 4.5 and $0.72 \mathrm{~m}$ under RCP 8.5) whereas the HWL indicator remains low (HWL is predicted to be $1.0 \mathrm{~m}$ under both RCP 4.5 and 8.5).

Nevertheless, coastal zones are particularly exposed to floods because the presence of low-lying inland zones exacerbate the effects of both wave storms and rainfall events $[64,65]$. The totality of the municipal area is indeed entirely included in the RICE area since the terrain elevations are always under $5 \mathrm{~m}$ above sea level so that inland areas are exposed to flood even in case of low return period wave storms [48]. 


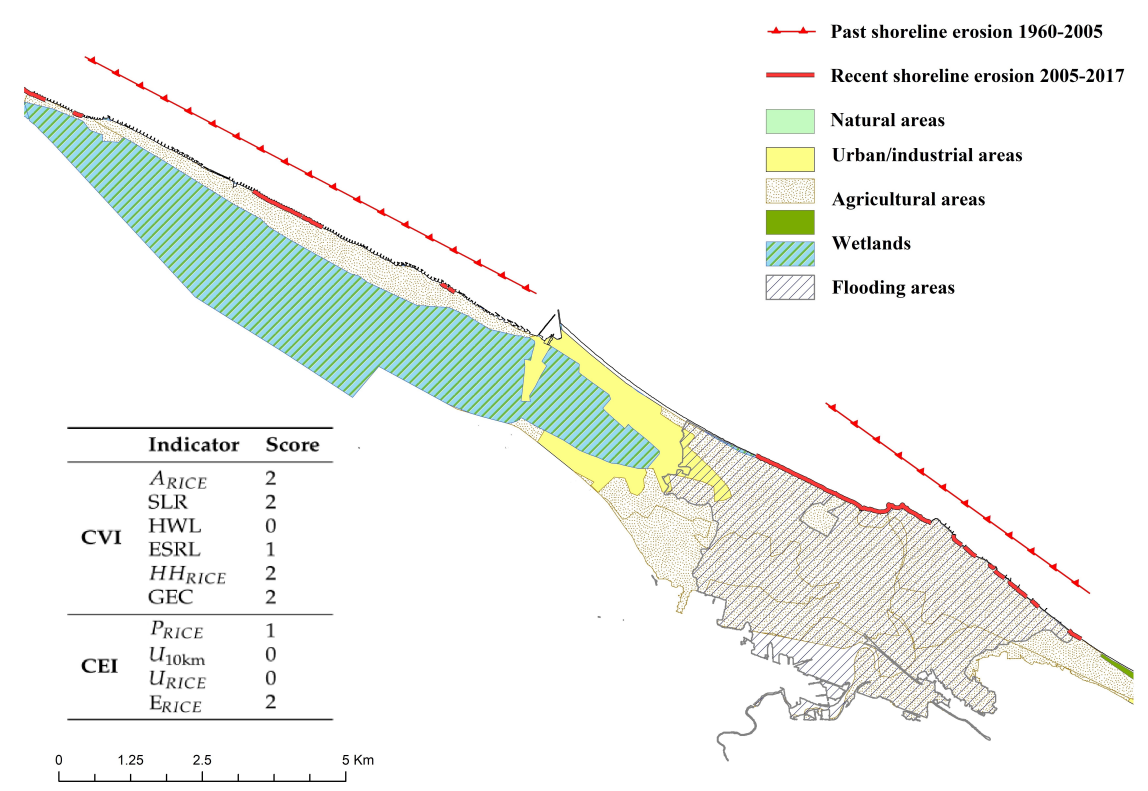

Figure 4. Land use, coastal erosion, and hydraulic hazard in the test site. The table reports CVI and CEI scores estimated under RCP 4.5 and 8.5 scenarios.

Shoreline evolution has been assessed, comparing historical maps and aerial photos and it was observed that more than $66 \%$ of the municipal shoreline has retreated in the period between 1960 and 2005 whereas in the last period (2005-2017) the erosive process has affected $30 \%$ of the coastline.

Flooding areas, as mapped in the Hydro-Geologic Safety Plan produced by the Apulian basin authority [66], cover about $1 / 3$ of the RICE area since a very wide area around the Ofanto river is at high risk of inundation.

The low exposure of the area, assessed using the CEI index, is almost entirely due to the high ecological areas that cover about half of the RICE area, whereas the urban/industrial settlements are very limited as reported in 2018 CORINE Land Cover maps [67]. In the summer period, tourist arrivals increase the population exposed to coastal risk. Despite the high vulnerability, since the low/medium exposure value, the Coastal Risk Index, normalized with respect the maximum value that could be estimated from the model, is ranked as medium.

\subsection{The Perceived Coastal Risk in the Test Site}

The perceived coastal risk in the test site was elicited through the process described in Section 2.2.

The Scenario Workshop took place on 9 May 2019 in the Municipality of Margherita di Savoia from 10 a.m. to 6 p.m. with the participation of 15 representatives of policy makers and stakeholders (Table 2). Participants recognized coastal erosion and the ineffectiveness of the existing coastal protection structures as the most significant problems for the pilot area. Moreover, they perceived the overexploitation of beaches as a problem as well, particularly for difficulties related to access to the beach. However, even though flooding is a recognized problem, especially for the agriculture sector, they did not perceive it.

Actors identified some obstacles/constraints and actions needed to overcome the highlighted problems and to allow effective management of the coastal area. In particular, they recognized the complexity and fragmentation of multilevel and multisectoral governance characterizing coastal areas. To solve this aspect, they believe that there is the necessity to promote more cooperation among different institutional actors at different scales and to activate participatory planning strategies. For a detailed description of the results of the Scenario Workshop, readers can refer to [23]. 
The results of the Scenario Workshop were graphically represented in the C-FCM (Figure 5). The map shows positive (green arrows) and negative (red arrows) influences between aspects as perceived by the participants. The left part of the map represents the physical aspects related to coastal erosion, the right part relates to coastal erosion monitoring and management for the study area.

Table 2. List of Scenario Workshop participants.
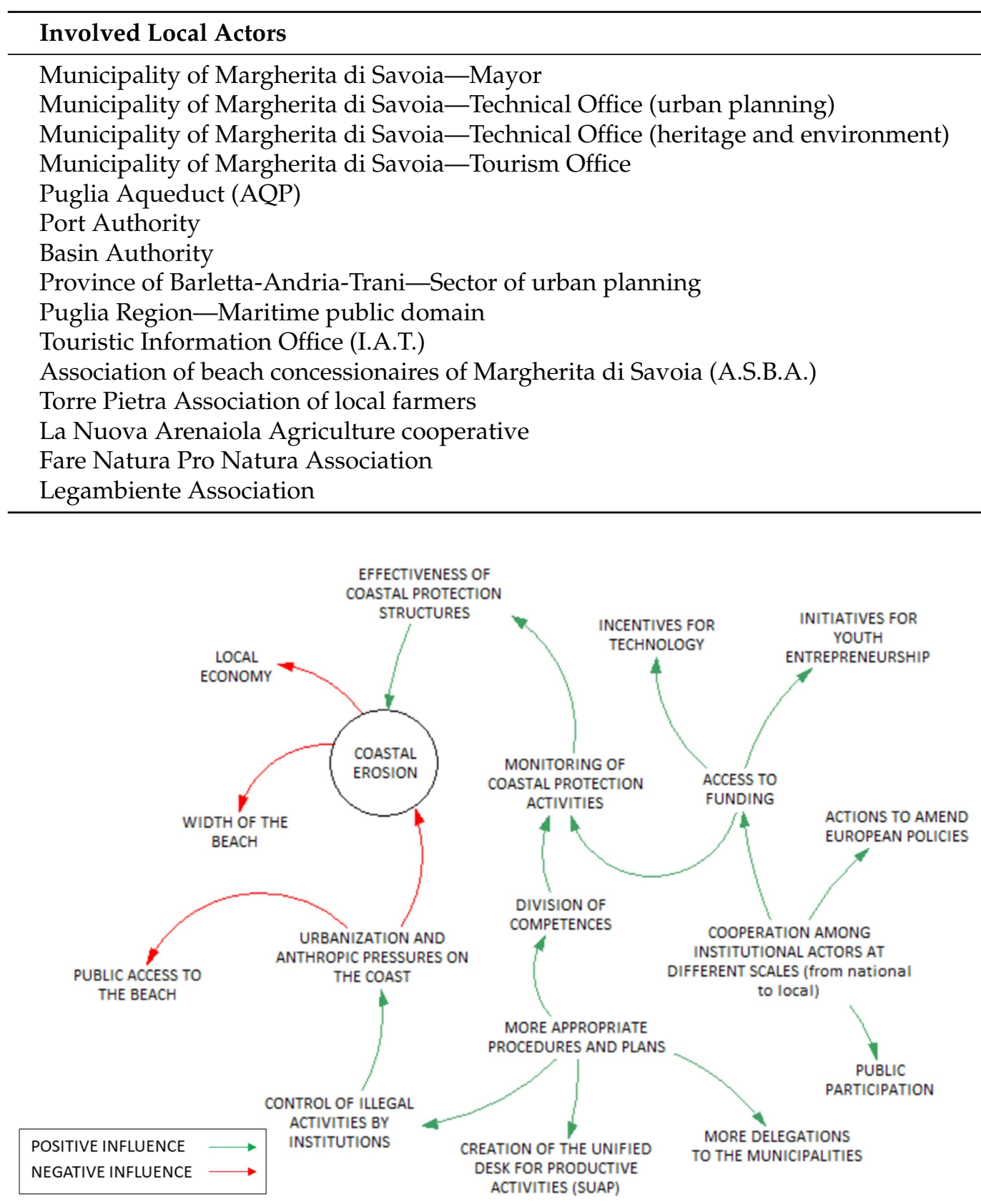

Figure 5. C-FCM of Step 3-the coastal risk perception in the test site as result of the Scenario Workshop.

Coastal erosion was identified as caused by the excessive urbanization and anthropic pressures on the coast. On the other hand, it exerted direct negative impacts on the local economy and the width of the beach.

Stakeholders and policy makers identified several actions that could positively influence the monitoring and management of this coastal area. First of all, the creation of more appropriate procedures and plans could improve the control of illegal activities by institutions and, consequently, reduce urbanization and anthropic pressures on the coast. As a 
matter of fact, illegal buildings along Puglia coastal areas is a serious problem, as demonstrated by different quantitative analysis, e.g., Mare Monstrum of Legambiente [68]. More appropriate procedures and plans would allow to (i) create the unified desk for productive activities (SUAP), (ii) define more delegations to the municipalities, and (iii) divide competencies. In this way, the latter aspect would enhance the monitoring of coastal protection structures, enabling their effectiveness and consequently resulting in a reduction of coastal erosion. Moreover, cooperation among institutional actors at different scales (from national to local) would improve (i) public participation, (ii) actions to amend European policies, and (iii) access to funding. Accordingly, the latter would promote incentives for technology, initiatives for youth entrepreneurship, and monitoring of coastal protection structures.

As a result of the individual sessions performed in Step 4, a new C-FCM was built (Figure 6). The map shows (i) the unchanged elements from the initial map of Step 3 (Figure 5), (ii) the differences and especially some new aspects identified by the actors, and (iii) issues that were particularly discussed and have led to the modification of concepts related to coastal monitoring and management actions.

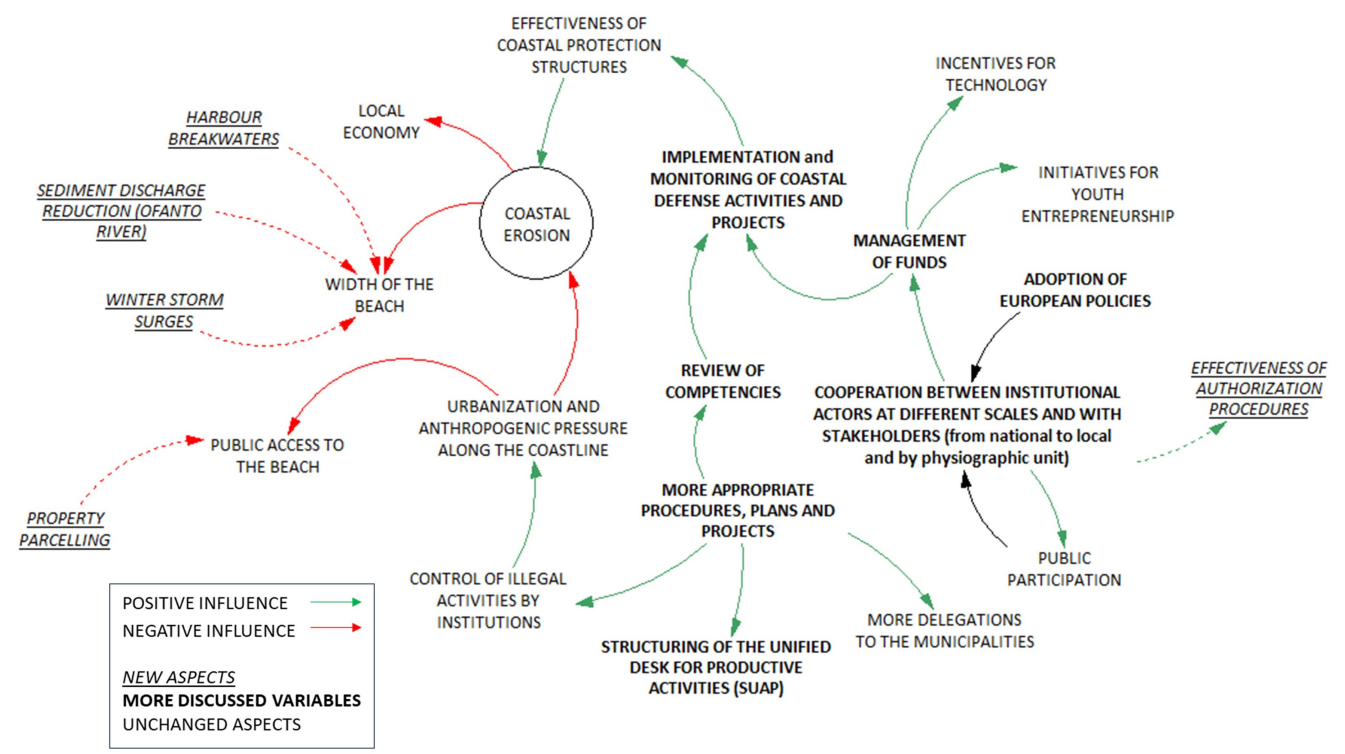

Figure 6. C-FCM of Step 4-the coastal risk perception in the test site as a result of the I-FCMs.

The actors identified new aspects as direct negative influences for the width of the beach: Firstly, the presence of the harbor breakwaters; secondly, the sediment discharge reduction of the Ofanto River; and finally the occurrence of winter storm surges. Furthermore, public access to the beach is perceived to be negatively affected by excessive property parceling. The most discussed aspects, reported in bold in Figure 6, regarding the right part of the map, focus on coastal monitoring and management actions. In particular, the need to review the administrative competencies to allow the implementation and monitoring of coastal protection structures and projects eemerged as an important topic. Moreover, the map shows that public participation and the adoption of European policies could have positive influences on cooperation (i) between institutional actors at different scales, (ii) with stakeholders from national to local, and (iii) by physiographic unit. Consequently, such an aspect would enhance the effectiveness of authorization procedures and the management of public funds. The latter, in turn, would allow the implementation and monitoring of coastal protection structures which, indirectly, would have a positive influence on coastal erosion through more effective coastal management.

As already described in Section 2.2, the last step of the designed process consisted in the evaluation of the Coastal Vulnerability and Exposure Indexes in Mod.E.M by the involved people (Table 3). What emerges is that policy makers and stakeholders have a correct perception of the risk drivers, highlighting a considerable knowledge of their 
territory. If appropriately solicited, they have also demonstrated awareness of larger-scale environmental issues such as SLR, that they had not mentioned in the previous steps.

With reference to the CEI indicators, it is evident that they homogeneously consider the urban and high ecological value areas highly exposed to coastal risk, while seeming to underestimate population exposure. Instead, they show a heterogeneous perception of land use changes. They have also stressed the need to include in the evaluations agricultural areas, which represent one of the primary income sources.

Table 3. Perceived Coastal Risk Index by stakeholders and policy makers in Mod.E.M.

\begin{tabular}{|c|c|c|c|c|c|c|c|}
\hline & & \multicolumn{6}{|c|}{ Scores } \\
\hline \multirow{8}{*}{ 己 } & Indicator & Act. 1 & Act. 2 & Act. 3 & Act. 4 & Act. 5 & Act. 6 \\
\hline & $A_{\text {RICE }}$ & 2 & 2 & 2 & 1 & 2 & 2 \\
\hline & SLR & 2 & 1 & 0 & 2 & 2 & 2 \\
\hline & HWL & 0 & 1 & 0 & 2 & 0 & 2 \\
\hline & ESRL & 2 & 1 & 2 & 2 & 2 & 2 \\
\hline & $H H_{R I C E}$ & 2 & 2 & 2 & 1 & 1 & 2 \\
\hline & GEC & 2 & 2 & 2 & 2 & 2 & 2 \\
\hline & CVI & 10 & 9 & 8 & 10 & 9 & 12 \\
\hline \multirow{6}{*}{ 폰 } & $P_{R I C E}$ & 1 & 2 & 1 & 1 & 2 & 0 \\
\hline & $U_{10 \mathrm{~km}}$ & 0 & 1 & 0 & 2 & 2 & 0 \\
\hline & $U_{R I C E}$ & 2 & 1 & 2 & 2 & 2 & 1 \\
\hline & $E_{R I C E}$ & 2 & 2 & 2 & 2 & 2 & 2 \\
\hline & CEI & 5 & 6 & 5 & 7 & 8 & 3 \\
\hline & Costal risk index & 50 & 54 & 40 & 70 & 72 & 36 \\
\hline
\end{tabular}

\section{Discussion}

The "physical" evaluation of coastal risk indicators in the study area highlighted three main issues: A remarkable erosive process that started from 1960 and is currently going on, the presence of a protected natural area that includes the saltworks and wide flood-prone areas. Nevertheless, these aspects are only partially recognized by stakeholders and policy makers.

People involved in the process will perceive the risk of coastal erosion for the test site, while they do not recognize the risk associated with flooding that frequently affects the study area. This was despite the fact that the stakeholders included two representatives of farmers, i.e., the category most affected by the floods. Probably floods are so closely associated with coastal erosion in the study area that local actors subsumed them into erosive processes.

From the analysis, it emerges that the excessive urbanization and anthropogenic pressures along the coast are recognized as one of the main causes of erosion processes and that coastal protection structures have worsened the problem instead of reducing it. It is quite clear that they are aware of the history of the area. Climate change's negative impacts, as projected under the worst RCP Scenario (4.5 and 8.5), are not perceived by the actors and it could be since they have difficulties placing the local reality in a more global context. In this regard, as argued by Metzger [69], the involved actors could be defined as "territorial stakeholders" because their way of thinking is articulated in a particular territorial framing due to the integration of social, environmental, and economic relationships "territorially".

The risk perception elicitation also highlights the main issues related to management activities: They believe that for a correct management of the coastal area of Margherita di Savoia, there is the need to cooperate between institutional actors at different scales and with stakeholders. Moreover, the correct coastal management must also include capillary control of all activities on the coast. Looking at the evaluation of the CVI and CEI, it is notable that the actors have a proper perception of vulnerability factors, even those that were not initially perceived (e.g., SLR and $\left.H H_{R I C E}\right)$. On the contrary, there is a high 
perception of the exposed assets, especially for the urbanized area. Stakeholders and policy makers highlight the need to also include agricultural areas in the CEI because it has a high economic value for the area given due to the high-quality agriculture products. In this case, the application of the Mod.E.M. method by the experts at a wider scale ignores the impacts on a local economy that essentially thrives on activities heavily impacted by erosion and flooding.

The combination of a traditional index-based model with the active engagement of stakeholders and policy makers for the evaluation of the coastal risk in the test site allows to add new elements to the risk assessment and in particular to the exposure. This is because the deep knowledge of the site by the people involved helps to grasp elements that are characteristic of that local context and that are difficult to catch for people who do not inhabit such areas.

As demonstrated, the misalignment in exposure assessment results is problematic if problems facing coastal areas can be better managed when stakeholders are directly involved in the management process. Therefore, stating that risk assessment is the only way to determine policy choices at the regional or national level, this situation may be a disadvantage in some local contexts causing loss of confidence or vindictive attitudes by local actors.

Thus, the Mod.E.M. method is useful in identifying coastal erosion and flooding hot spots within a wider area, such as the regional level. Nevertheless, the integrated approach proposed in this study highlights the need to do more detailed studies to assess risk at the municipal level both including mathematical modeling in vulnerability estimation and the experiential knowledge of local actors in exposure evaluation.

\section{Conclusions}

A novel integrated approach for coastal risk evaluation exploiting a DPSIR framework and the risk perception by policy makers and stakeholders collected through a Scenario Workshop and structured using Fuzzy-Cognitive Maps was presented and tested in a pilot area. Margherita di Savoia was selected as a test site due to the high rates of erosion and flooding hazards that have heavily degraded the natural environment and sustainability of coastal areas. The comparison between a traditional index-based model and the risk perception, highlights that local stakeholders and policy makers have a correct perception of the significant erosive process that affect the coastline from several decades. On the contrary, some relevant risk drivers detected from the "physical" approach did not emerge during the Workshop. For example, the Scenario Workshop did not reveal flooding experience and their the negative effects, nevertheless the inland territories are often subject to floods induced by sea waves and rainfall events, embittered by SLR. On the other hand, these aspects emerged in the stakeholders' perception when the actors were asked to score the indicators used in coastal risk assessment. The comparison also highlighted a high perception of assets exposed to coastal risk. The combination of the two approaches for the evaluation of the coastal risk in the test site allows one to add new elements to the risk assessment and in particular to the exposure. This is because the deep knowledge of the site by the people involved helps to grasp elements that are characteristic of that local context and that are difficult to catch for people who do not inhabit such areas. Since stakeholders' and policy makers' risk perception plays a key role in coastal risk management, the integration of physical risk with social perception is relevant to improve management effectiveness also following the basics of ICZM. Accordingly, the involvement of local actors in the risk assessment surely increases public knowledge and preparedness and effectively reduces both exposure and vulnerability.

Author Contributions: Conceptualization, M.F.B., G.M.Z. and A.B.; methodology, M.F.B., G.M.Z. and A.B.; software, M.F.B. and G.M.Z.; validation, M.F.B. and G.M.Z.; formal analysis, M.F.B. and G.M.Z.; investigation, M.F.B., G.M.Z. and A.B.; resources, M.F.B. and G.M.Z.; data curation, M.F.B. and G.M.Z.; writing—original draft preparation, M.F.B. and G.M.Z.; writing—review and editing, M.F.B., G.M.Z., A.B. and L.D.; visualization, M.F.B. and G.M.Z.; supervision, A.B. and L.D.; project 
administration, L.D.; funding acquisition, L.D. All authors have read and agreed to the published version of the manuscript.

Funding: The present study is part of the STIMARE project, funded by the Italian Ministry for the Environment and Protection of the Territory and the Sea-C.U.P. J56C18001240001.

Institutional Review Board Statement: Not applicable.

Informed Consent Statement: Informed consent was obtained from all subjects involved in the study.

Data Availability Statement: Publicly available datasets were analyzed in this study. Data are available here: (i) Web Map Services (WMS) for Apulian region: http:/ / www.sit.puglia.it/portal/ (accessed on 23 June 2021); (ii) 2018 Corine Land Cover: https:/ /land.copernicus.eu (accessed on 23 June 2021), (iii) to get access to the interviews, please contact the authors.

Conflicts of Interest: The authors declare no conflict of interest.

\section{References}

1. Neumann, B.; Vafeidis, A.T.; Zimmermann, J.; Nicholls, R.J. Future coastal population growth and exposure to sea-level rise and coastal flooding-a global assessment. PLoS ONE 2015, 10, e0118571. [CrossRef]

2. Vousdoukas, M.I.; Mentaschi, L.; Voukouvalas, E.; Bianchi, A.; Dottori, F.; Feyen, L. Climatic and socioeconomic controls of future coastal flood risk in Europe. Nat. Clim. Chang. 2018, 8, 776-780. [CrossRef]

3. Adger, W.; Hughes, T.; Folke, C.; Carpenter, S.R.; Rockström, J. Social-ecological resilience to coastal disasters. Science 2005, 309, 1036-1039. [CrossRef] [PubMed]

4. Crichton, D. The risk triangle. In Natural Disaster Management; Ingleton, J., Ed.; Tudor Rose: London, UK, $1999 ;$ pp. $102-103$.

5. Cardona, O.D.; Van Aalst, M.K.; Birkmann, J.; Fordham, M.; Mc Gregor, G.; Rosa, P.; Pulwarty, R.S.; Schipper, E.L.F.; Sinh, B.T.; Décamps, H.; et al. Determinants of risk: Exposure and vulnerability. In Managing the Risks of Extreme Events and Disasters to Advance Climate Change Adaptation: Special Report of the Intergovernmental Panel on Climate Change; Cambridge University Press: Cambridge, UK, 2012; pp. 65-108.

6. Vousdoukas, M.I.; Ranasinghe, R.; Mentaschi, L.; Plomaritis, T.A.; Athanasiou, P.; Luijendijk, A.; Feyen, L. Sandy coastlines under threat of erosion. Nat. Clim. Chang. 2020, 10, 260-263. [CrossRef]

7. Kirezci, E.; Young, I.R.; Ranasinghe, R.; Muis, S.; Nicholls, R.J.; Lincke, D.; Hinkel, J. Projections of global-scale extreme sea levels and resulting episodic coastal flooding over the 21st Century. Sci. Rep. 2020, 10, 1-12. [CrossRef] [PubMed]

8. Pellicani, R.; Argentiero, I.; Fidelibus, M.D.; Motta Zanin, G.; Parisi, A.; Spilotro, G. Dynamics of the Basilicata Ionian coast: Human and natural drivers. Rend. Lincei. Sci. Fis. E Nat. 2020, 31, 353-364. [CrossRef]

9. Parisi, A.; Monno, V.; Fidelibus, M. Cascading vulnerability scenarios in the management of groundwater depletion and salinization in semi-arid areas. Int. J. Disaster Risk Reduct. 2018, 30, 292-305. [CrossRef]

10. Folke, C.; Hahn, T.; Olsson, P.; Norberg, J. Adaptive governance of social-ecological systems. Annu. Rev. Environ. Resour. 2005, 30, 441-473. [CrossRef]

11. Holling, C.S. Resilience and stability of ecological systems. Annu. Rev. Ecol. Syst. 1973, 4, 1-23. [CrossRef]

12. Hinkel, J.; Klein, R.J. Integrating knowledge to assess coastal vulnerability to sea-level rise: The development of the DIVA tool. Glob. Environ. Chang. 2009, 19, 384-395. [CrossRef]

13. Torresan, S.; Critto, A.; Rizzi, J.; Marcomini, A. Assessment of coastal vulnerability to climate change hazards at the regional scale: The case study of the North Adriatic Sea. Nat. Hazards Earth Syst. Sci. 2012, 12, 2347-2368. [CrossRef]

14. Zanuttigh, B.; Simcic, D.; Bagli, S.; Bozzeda, F.; Pietrantoni, L.; Zagonari, F.; Hoggart, S.; Nicholls, R.J. THESEUS decision support system for coastal risk management. Coast. Eng. 2014, 87, 218-239. [CrossRef]

15. Van Dongeren, A.; Ciavola, P.; Martinez, G.; Viavattene, C.; Bogaard, T.; Ferreira, O.; Higgins, R.; McCall, R. Introduction to RISC-KIT: Resilience-increasing strategies for coasts. Coast. Eng. 2018, 134, 2-9. [CrossRef]

16. Estrela-Segrelles, C.; Gomez-Martinez, G.; Perez-Martin, M.A. Risk assessment of climate change impacts on Mediterranean coastal wetlands. Application in Jucar River Basin District (Spain). Sci. Total Environ. 2021, 790, 148032. [CrossRef]

17. Cogswell, A.; Greenan, B.J.; Greyson, P. Evaluation of two common vulnerability index calculation methods. Ocean Coast. Manag. 2018, 160, 46-51. [CrossRef]

18. Gornitz, V.M.; Daniels, R.C.; White, T.W.; Birdwell, K.R. The development of a coastal risk assessment database: Vulnerability to sea-level rise in the US Southeast. J. Coast. Res. 1994, 12, 327-338.

19. Mosley, S. Coastal cities and environmental change. Environ. Hist. 2014, 20, 517-533. [CrossRef]

20. Barragán, J.M.; de Andrés, M. Analysis and trends of the world's coastal cities and agglomerations. Ocean Coast. Manag. 2015, 114, 11-20. [CrossRef]

21. Besio, G. Il Progetto Della Costa: Le Sistemazioni Costiere; Donzelli: Roma, Italy, 2014.

22. Dreyer, M.; Boström, M.; Jönsson, A.M. Participatory deliberation, risk governance and management of the marine region in the European Union. J. Environ. Policy Plan. 2014, 16, 497-515. [CrossRef] 
23. Motta Zanin, G. The role of experiential knowledge in risk management of coastal landscapes. A case study in the Mediterranean Basin. In Landscape at Risk; Luciano Editore: Napoli, Italy, 2020.

24. Salomons, W.; Turner, K.; de Lacerda, L.D.; Ramachandran, S. Perspectives on Integrated Coastal Zone Management; Springer Science \& Business Media: Berlin/Heidelberg, Germany, 2012.

25. Environmental European Commission. Recommendation of the European Parliament and of the Council of 30 May 2002 Concerning the Implementation of Integrated Coastal Zone Management in Europe. Off. J. Eur. Commun 2002, 148, $22-27$.

26. Alterman, R.; Pellach, C. Regulating Coastal Zones: International Perspectives on Land Management Instruments; Routledge: London, $\mathrm{UK}, 2020$.

27. Bruno, M.F.; Saponieri, A.; Molfetta, M.G.; Damiani, L. The DPSIR Approach for Coastal Risk Assessment under Climate Change at Regional Scale: The Case of Apulian Coast (Italy). J. Mar. Sci. Eng. 2020, 8, 531. [CrossRef]

28. Costas, S.; Ferreira, O.; Martinez, G. Why do we decide to live with risk at the coast? Ocean Coast. Manag. 2015, 118, 1-11. [CrossRef]

29. Mani-Peres, C.; Xavier, L.Y.; Santos, C.R.; Turra, A. Stakeholders perceptions of local environmental changes as a tool for impact assessment in coastal zones. Ocean Coast. Manag. 2016, 119, 135-145. [CrossRef]

30. Fatorić, S.; Morén-Alegret, R.; Niven, R.J.; Tan, G. Living with climate change risks: Stakeholders' employment and coastal relocation in mediterranean climate regions of Australia and Spain. Environ. Syst. Decis. 2017, 37, 276-288. [CrossRef]

31. Lemée, C.; Fleury-Bahi, G.; Krien, N.; Deledalle, A.; Mercier, D.; Coquet, M.; Rommel, D.; Navarro, O. Factorial structure of the coastal flooding risk perception and validation of a French coastal flooding risk evaluation scale (CFRES) for non-experts. Ocean Coast. Manag. 2018, 155, 68-75. [CrossRef]

32. UNDRR. Sendai Framework for Disaster Risk Reduction 2015-2030. Available online: https://www.undrr.org/publication/ sendai-framework-disaster-risk-reduction-2015-2030 (accessed on 23 June 2021).

33. IRGC. Involving Stakeholders in the Risk Governance Process; EPFL International Risk Governance Center: Lausanne, Switzerland, 2020.

34. Koutrakis, E.; Sapounidis, A.; Marzetti, S.; Marin, V.; Roussel, S.; Martino, S.; Fabiano, M.; Paoli, C.; Rey-Valette, H.; Povh, D.; et al. ICZM and coastal defence perception by beach users: Lessons from the Mediterranean coastal area. Ocean Coast. Manag. 2011, 54, 821-830. [CrossRef]

35. Gray, S.; Gagnon, A.; Gray, S.; O’Dwyer, B.; O’Mahony, C.; Muir, D.; Devoy, R.; Falaleeva, M.; Gault, J. Are coastal managers detecting the problem? Assessing stakeholder perception of climate vulnerability using Fuzzy Cognitive Mapping. Ocean Coast. Manag. 2014, 94, 74-89. [CrossRef]

36. Francis, O.P.; Kim, K.; Pant, P. Stakeholder assessment of coastal risks and mitigation strategies. Ocean Coast. Manag. 2019, 179, 104844. [CrossRef]

37. Schmidt, L.; Delicado, A.; Gomes, C.; Granjo, P.; Guerreiro, S.; Horta, A.; Mourato, J.; Prista, P.; Saraiva, T.; Truninger, M.; et al. Change in the way we live and plan the coast: Stakeholders discussions on future scenarios and adaptation strategies. J. Coast. Res. 2013, 65, 1033-1038. [CrossRef]

38. Gerkensmeier, B.; Ratter, B.M. Governing coastal risks as a social process-Facilitating integrative risk management by enhanced multi-stakeholder collaboration. Environ. Sci. Policy 2018, 80, 144-151. [CrossRef]

39. Slovic, P. Perception of risk. Science 1987, 236, 280-285. [CrossRef]

40. Jungk, R.; Müllert, N. Future Workshops: How to Create Desirable Futures; Inst. for Social Inventions: London, UK, 1987.

41. Santoro, S.; Motta Zanin, G. The role of stakeholders' risk perception in water management policies: A case study comparison in Southern Italy. In Smart and Sustainable Planning for Cities and Regions, Results of SSPCR; Springer: Cham, Switzerland, 2019.

42. Papageorgiou, E.; Kontogianni, A. Using fuzzy cognitive mapping in environmental decision making and management: A methodological primer and an application. Int. Perspect. Glob. Environ. Chang. 2012, 427-450. [CrossRef]

43. Özesmi, U.; Özesmi, S. A participatory approach to ecosystem conservation: Fuzzy cognitive maps and stakeholder group analysis in Uluabat Lake, Turkey. Environ. Manag. 2003, 31, 0518-0531. [CrossRef] [PubMed]

44. Gari, S.R.; Newton, A.; Icely, J.D. A review of the application and evolution of the DPSIR framework with an emphasis on coastal social-ecological systems. Ocean Coast. Manag. 2015, 103, 63-77. [CrossRef]

45. EEA. The Changing Faces of Europe's Coastal Areas; Number No. 6 in EEA Report; European Environment Agency: Copenhagen, Denmark, 2006.

46. Torres, J.M.; Bass, B.; Irza, N.; Fang, Z.; Proft, J.; Dawson, C.; Kiani, M.; Bedient, P. Characterizing the hydraulic interactions of hurricane storm surge and rainfall-runoff for the Houston-Galveston region. Coast. Eng. 2015, 106, 7-19. [CrossRef]

47. Lopez Diez, A.; Mayer Suarez, P.; Diaz Pacheco, J.; Dorta Antequera, P. Rainfall and Flooding in Coastal Tourist Areas of the Canary Islands (Spain). Atmosphere 2019, 10, 809. [CrossRef]

48. Apollonio, C.; Bruno, M.F.; Iemmolo, G.; Molfetta, M.G.; Pellicani, R. Flood risk evaluation in ungauged coastal areas: The case study of Ippocampo (Southern Italy). Water 2020, 12, 1466. [CrossRef]

49. Motta Zanin, G.; Bruno, M.F.; Saponieri, A. Understanding the Importance of Risk Perception in Coastal Socio-Ecological Systems Management: A Case Study in Southern Italy. In Innovation in Urban and Regional Planning: Proceedings of the 11th INPUT Conference-Volume 1; Springer: Berlin/Heidelberg, Germany, 2021; p. 235.

50. Vidal, R.V.V. The future workshop: Democratic problem solving. Econ. Anal. Work. Pap. 2006, 5, 21. 
51. Stylios, C.D.; Georgopoulos, V.C.; Malandraki, G.A.; Chouliara, S. Fuzzy cognitive map architectures for medical decision support systems. Appl. Soft Comput. 2008, 8, 1243-1251. [CrossRef]

52. Van Vliet, M.; Kok, K.; Veldkamp, T. Linking stakeholders and modellers in scenario studies: The use of Fuzzy Cognitive Maps as a communication and learning tool. Futures 2010, 42, 1-14. [CrossRef]

53. Valentini, N.; Saponieri, A.; Danisi, A.; Pratola, L.; Damiani, L. Exploiting remote imagery in an embayed sandy beach for the validation of a runup model framework. Estuar. Coast. Shelf Sci. 2019, 225, 106244. [CrossRef]

54. Bruno, M.F.; Molfetta, M.G.; Pratola, L.; Mossa, M.; Nutricato, R.; Morea, A.; Nitti, D.O.; Chiaradia, M.T. A Combined Approach of Field Data and Earth Observation for Coastal Risk Assessment. Sensors 2019, 19, 1399. [CrossRef]

55. Spinosa, A.; Ziemba, A.; Saponieri, A.; Damiani, L.; El Serafy, G. Remote sensing-based automatic detection of shoreline position: A case study in apulia region. J. Mar. Sci. Eng. 2021, 9, 575. [CrossRef]

56. Russo, S. Margherita di Savoia. Storia di una Comunità nella Prima Metà del Novecento; Claudio Grenzi Editore: Foggia, Italy, 2020.

57. Regional Tourism Agency-Puglia Region. Report Movimento Turistico Annuale per Comune: Anno 2019 [Annual Tourism Movement Report by Municipality: Year 2019]. 2019. Available online: https:// www.agenziapugliapromozione.it (accessed on 23 June 2021).

58. Archetti, R.; Damiani, L.; Bianchini, A.; Romagnoli, C.; Abbiati, M.; Addona, F.; Airoldi, L.; Cantelli, L.; Gaeta, M.G.; Guerrero, M.; et al. Innovative strategies, monitoring and analysis of the coastal erosion risk: The STIMARE project. In Proceedings of the 29th International Ocean and Polar Engineering Conference, International Society of Offshore and Polar Engineers, Honolulu, HI, USA, 16-21 June 2019.

59. Damiani, L.; Petrillo, A.; Ranieri, G. Management of coastal area in Apulia Region. Landsc. Water Hist. Innov. Sustain 2002, $1,71-80$.

60. Armenio, E.; Serio, F.D.; Mossa, M.; Petrillo, A.F. Coastline evolution based on statistical analysis and modeling. Nat. Hazards Earth Syst. Sci. 2019, 19, 1937-1953. [CrossRef]

61. De Santis, V.; Caldara, M.; Marsico, A.; Capolongo, D.; Pennetta, L. Evolution of the Ofanto River delta from the 'Little Ice Age'to modern times: Implications of large-scale synoptic patterns. Holocene 2018, 28, 1948-1967. [CrossRef]

62. Pellegrini, M.; Aghakhani, A.; Gaeta, M.G.; Archetti, R.; Guzzini, A.; Saccani, C. Effectiveness Assessment of an Innovative Ejector Plant for Port Sediment Management. J. Mar. Sci. Eng. 2021, 9, 197. [CrossRef]

63. Vousdoukas, M.I.; Mentaschi, L.; Voukouvalas, E.; Verlaan, M.; Jevrejeva, S.; Jackson, L.P.; Feyen, L. Global probabilistic projections of extreme sea levels show intensification of coastal flood hazard. Nat. Commun. 2018, 9, 1-12. [CrossRef]

64. Bruno, M.; Molfetta, M.; Petrillo, A. The influence of interannual variability of mean sea level in the Adriatic Sea on extreme values. J. Coast. Res. 2014, 70, 241-246. [CrossRef]

65. Pasquali, D.; Bruno, M.; Celli, D.; Damiani, L.; Di Risio, M. A simplified hindcast method for the estimation of extreme storm surge events in semi-enclosed basins. Appl. Ocean Res. 2019, 85, 45-52. [CrossRef]

66. Apulian Regional Watershed Authority. Piano Stralcio di Assetto Idrogeologico (PAI). 2005. Available online: http://www.adb. puglia.it (accessed on 23 June 2021).

67. European Union Copernicus Land Monitoring Service. 2018 Corine Land Cover. 2018. Available online: https://land.copernicus. eu (accessed on 23 June 2021).

68. Legambiente. Mare Monstrum. 2021. Available online: https://www.legambiente.it/rapporti-in-evidenza/mare-monstrum/ (accessed on 16 July 2021).

69. Metzger, J. Placing the stakes: The enactment of territorial stakeholders in planning processes. Environ. Plan. A 2013, 45, 781-796. [CrossRef] 